\title{
STUDI KASUS KESULITAN BELAJAR MATEMATIKA SISWA KELAS I, II \& III DI SD NEGERI 009 BALIKPAPAN SELATAN
}

\author{
Mely Safitri ${ }^{1}$, Casmudi ${ }^{2}$, Ryan Angga Pratama ${ }^{3}$ \\ Universitas Balikpapan ${ }^{1}$, Universitas Balikpapan ${ }^{2}$, Universitas Balikpapan ${ }^{3}$ \\ pos-el: syafitri.ms@gmail.com ${ }^{1}$, casmudi@uniba-bpn.ac.id ${ }^{2}$,ryan.angga@uniba-bpn.ac.id ${ }^{3}$
}

\begin{abstract}
ABSTRAK
Matematika merupakan sarana untuk memecahkan masalah dalam kehidupan sehari-hari sehingga perlu dikuasai dengan baik, namun sebagian besar siswa mengganggap bahwa matematika adalah pelajaran yang sulit, khususnya kelas I, II \& III di SD Negeri 009 Balikpapan Selatan. Tujuan penelitian ini adalah untuk mendeskripsikan kesulitan belajar siswa, faktor-faktor penyebab kesulitan belajar siswa dan hambatan dalam mengenali penyebab kesulitan belajar siswa di SD Negeri 009 Balikpapan Selatan. Penelitian ini adalah adalah penelitian yang bersifat kualitatif dengan subjek 9 siswa yang terindikasi kesulitan belajar matematika dan 3 guru kelas untuk membimbing dan mendampingi siswa. Teknik yang digunakan untuk mengumpulkan data adalah observasi, wawancara dan studi dokumentasi. Analisis data yang dilakukan adalah reduksi data, penyajian data dan penarikan kesimpulan. Hasil penelitian menunjukan kesulitan yang dialami siswa dalam pembelajaran matematika yaitu, kesulitan memahami konsep, kesulitan dalam keterampilan perhitungan, kesulitan memecahkan masalah, kesulitan memahami simbol, dan penggunaan proses yang keliru. Faktor yang mempengaruhi kesulitan belajar faktor internal diantaranya, sikap belajar matematika siswa, minat belajar matematika siswa, motivasi belajar matematika siswa dan kemampuan penginderaan serta kesehatan tubuh. Faktor eksternal diantaranya penggunaan media pembelajaran, sarana dan prasarana sekolah, dan lingkungan keluarga. Hambatan dalam mengenali penyebab kesulitan belajar siswa adalah lingkungan sekolah serta motivasi dan sikap.
\end{abstract}

Kata kunci: kesulitan, belajar, matematika.

\begin{abstract}
Mathematics is a means to solve a problem in everybody life so that it needs to be mastered well, but most of students assume that mathematics is a difficult lesson, especially from classes I, II \& III at Elementary School 009 of South Balikpapan. The purpose of the research was to describe a difficult learning of students, factors the cause student learning difficulties and obstacles in recognizing the causes of student learning difficulties at Elementary School 009 of South Balikpapan. The research was a qualitative descriptive research with 9 students who indicated mathematics learning difficulties and 3 class teachers to guide and assist students. The technique used to collecting data was observation, interview and documentation study. Data analysis have done is data reduction, presentation data and conclusion drawing. The result showed the difficulties experienced by students in learning mathematics that is, difficulty understanding concepts, difficulties in calculation skills, difficulty solving problems, difficulties understanding symbols and incorrect use of processes. Factors that influence learning difficulties were internal factors such as students mathematics learning attitudes, students interest in learning mathematics, students mathematics learning motivation and body sensing infrastructure, and family environment. Obstacles in recognizing the causes of student learning difficulties were the school environment, motivation and attitude.
\end{abstract}

Keywords: difficulties, learning, mathematics. 


\section{PENDAHULUAN}

Setiap anak memiliki karakter yang berbeda, begitu juga dalam hal kemampuan akademis. Dalam proses belajar mengajar masih banyak siswa yang mengalami kesulitan dalam belajar. Menurut (Jamaris, 2014, p. 4) kesulitan belajar tidak hanya dialami oleh siswasiswa yang berkemampuan rendah saja tetapi dialami juga oleh siswa-siswa yang berkemampuan tinggi. Selain itu, siswa yang berkemampuan rata-rata juga mengalami kesulitan dalam belajar. Sedangkan kesulitan belajar ini merupakan kondisi proses belajar yang ditandai oleh hambatan-hambatan tertentu untuk mencapai prestasi anak di sekolah.

Siswa yang mengalami hambatan dalam menguasai keterampilan belajar akan mengalami kesulitan dalam belajarnya. Hal ini sejalan dengan pendapat Djamarah (Rusgiarti, 2014, p. 104) bahwa kesulitan belajar adalah suatu kondisi dimana anak didik tidak dapat belajar secara wajar disebabkan adanya ancaman, hambatan atau gangguan dalam belajar. Adanya hambatan-hambatan tersebut akan berakibat pada tujuan belajar yang tidak tercapai.

Salah satu kesulitan belajar yang sering dialami siswa adalah kesulitan belajar matematika. Dalam upaya mencapai tujuan dari pembelajaran matematika masih terdapat berbagai masalah yang menyebabkan tujuan pembelajaran belum tercapai secara maksimal karena masih banyak siswa yang mengalami kesulitan dalam pembelajaran matematika. Dalam pembelajaran matematika, jika siswa mengalami kesulitan belajar dianggap sebuah hal yang biasa dan sudah realita umumnya seperti itu. Hal ini disebabkan karena matematika merupakan pelajaran yang menjadi momok menakutkan bagi siswa. Matematika dianggap sebagai ilmu yang sulit untuk dipahami karena abstrak. Hal ini sejalan dengan pendapat (Abdurrahman, 2010, p. 252) mengemukakan bahwa dari berbagai bidang studi yang diajarkan di sekolah, matematika merupakan bidang studi yang dianggap paling sulit oleh para siswa baik yang tidak berkesulitan belajar matematika dan lebih-lebih siswa yang berkesulitan belajar matematika.

Kesulitan belajar dalam mata pelajaran matematika memiliki corak dan karakteristik sendiri apabila dibandingkan dengan kesulitan belajar dalam mata pelajaran lain. Menurut Abdurrahman (Yeni, 2015, p. 4) kesulitan belajar matematika disebut juga diskalkulia. Selanjutnya, Vaughn (Yeni, 2015, p. 4) berpendapat diskalkulia memiliki konotasi medis, yang memandang adanya keterkaitan dengan gangguan sistem saraf pusat. Diskalkulia juga mengacu pada konsep-konsep matematika dan komputasi.

Setiap siswa dengan kesulitan matematika adalah unik, tidak semua anak menunjukan kekurangan atau kesulitan yang sama. Menurut Wood (Untari, 2013, p. 2) bahwa beberapa karakteristik kesulitan siswa dalam belajar matematika adalah : (1) kesulitan membedakan angka, simbol-simbol, serta bangun ruang, (2) tidak sanggup mengingat dalil-dalil matematika, (3) menulis angka tidak terbaca atau dalam ukuran kecil, (4) tidak memahami simbolsimbol matematika, (5) lemahnya kemampuan berpikir abstrak, (6) lemahnya kemampuan metakognisi (lemahnya kemampuan mengidentifikasi serta memanfaatkan algoritma dalam memecahkan soal-soal matematika).

Berkaitan dengan kesulitan belajar dalam pembelajaran matematika, Sudjono (Yeni, 2015, pp. 5-6) mengklasifikasikan kesulitan belajar matematika yang difokuskan pada faktor penyebabnya dibedakan atas faktor dasar umum dan faktor dasar khusus. Faktor dasar umum adalah faktor-faktor yang secara umum menjadi penyebab kesulitan belajar siswa, seperti faktor fisiologis, faktor intelektual, faktor pedagogik, faktor sarana, dan faktor lingkungan. Sedangkan faktor 
dasar khusus adalah faktor yang secara spesifik menjadi penyebab siswa mengalami kesulitan melakukan aktifitas belajar, seperti menggunakan konsep, keterampilan operasi aritmatika, dan menyelesaikan soal cerita.

Berdasarkan wawancara dengan beberapa guru kelas I, II \& III di SD Negeri 009 Balikpapan Selatan masih banyak siswa yang mengalami kesulitan dalam pembelajaran matematika, ditandai dengan prestasi akademik yang rendah. Hal ini dapat terlihat dari nilai ulangan harian masih banyak siswa yang memperoleh nilai dibawah Kriteria Ketuntasan Minimal (KKM). Secara umum siswa masih kesulitan dalam memahami konsep dasar matematika serta kesulitan dalam berhitung. Kekeliruankekeliruan pada konsep dasar matematika akan menyebabkan siswa kesulitan dalam mempelajari konsep berikutnya, sehingga akan sulit pula dalam mempelajari pelajaran matematika.

Berdasarkan wawancara dengan guru siswa kelas I, II \& III, kebanyakan siswa yang mengalami kesulitan belajar matematika dijenjang kelas tinggi dikarenakan dari kelas I, II \& III sudah mengalami kesulitan belajar matemgatika, dimana kelas I, II, dan III merupakan jenjang anak mempelajari konsep-konsep dasar dalam pembelajaran matematika. Adapun yang membedakan penelitian ini dengan penelitian terdahulu yaitu penelitian terdahulu lebih difokuskan pada satu kelas sementara dalam penelitian ini difokuskan pada kesulitan belajar matematika siswa kelas I, II \& III, dengan penelitian ini diharapkan guru bisa mengetahui kesulitan belajar anak sejak dini serta faktor penyebabnya sehingga bisa memudahkan guru mengatasi kesulitan belajar siswa kelas I, II \& III dalam pembelajaran matematika. Oleh karena itu, penting untuk dilakukan penelitian dengan judul "Studi Kasus Kesulitan Belajar Matematika Siswa Kelas I, II \& III di SD Negeri 009 Balikpapan Selatan".

\section{METODE PENELITIAN}

Penelitian ini adalah penelitian yang bersifat kualitatif. Penelitian yang digunakan yaitu penelitian kualitatif jenis deskriptif dengan metode studi kasus (case study). Penentuan subjek penelitian atau responden dalam penelitian ini dilakukan dengan cara purposive sampling. Dalam penelitian ini subjek penelitian adalah 9 siswa yang terindikasi mengalami kesulitan belajar pada materi pelajaran matematika yaitu 3 siswa kelas I, 3 siswa kelas II dan 3 siswa kelas III dan 3 guru kelas I, II \& III.

Teknik pengumpulan data penelitian ini menggunakan teknik wawancara, observasi dan studi dokumentasi. Menurut Sugiyono (2014, p. 305) dalam penelitian kualitatif, yang menjadi instrumen atau alat penelitian adalah peneliti itu sendiri. Selain peneliti sendiri, instrumen lain yang mendukung dalam penelitian ini diantaranya 1) pedoman wawancara, digunakan sebagi panduan peneliti dalam mewawancarai narasumber 2) pedoman observasi digunakan untuk mengamati narasumber pada melakukan kegiatan belajar, dan 3) pedoman dokumentasi berupa foto-foto, rekaman wawancara.

Dalam penelitian ini untuk mendapatkan keabsahan data dilakukan dengan triangulasi teknik. Triangulasi teknik dalam penelitian ini dilakukan dengan cara mengecek data kepada sumber yang sama dengan teknik yang berbeda. Triangulasi teknik penelitian ini menggunakan teknik wawancara, observasi, dan dokumentasi.

Model analisis data dalam penelitian ini mengikuti konsep yang diberikan Miles \& Hubermen yaitu reduksi data sebagai proses pemilihan, pemusatan perhatian pada penyederhanaan, pengabstrakan dan transformasi data " kasar" yang muncul dari catatan-catatan kecil di lapangan, Setelah dilakukan reduksi data, langkah selanjutnya adalah penyajian data dilakukan dengan tujuan 
memahami informasi yang terjadi di lapangan, yang terakhir kesimpulan dalam penelitian ini diharapkan temuan berupa deskripsi atau gambaran suatu objek yang sebelumnya masih samar, kemudian diteliti agar lebih jelas. Kesimpulan ini digunakan untuk menjawab rumusan masalah yang telah ditentukan.

\section{HASIL DAN PEMBAHASAN \\ Kesulitan Siswa Dalam Memahami Materi Matematika}

Berdasarkan hasil wawancara siswa yang terindikasi mengalami kesulitan belajar matematika dan guru kelas, observasi didalam pembelajaran matematika dan studi dokumentasi, diketahui beberapa kesulitan yang dialami siswa yang berkesulitan belajar matematika diantaranya.

\section{a. Kesulitan dalam Memahami Konsep}

Pada observasi pembelajaran di kelas I SD Negeri 009 Balikpapan Selatan, peneliti menemukan bahwa siswa belum memahami secara tepat konsep nilai tempat. Kesulitan siswa yang dalam memahami konsep nilai tempat ditandai dengan kesulitan siswa ketika menentukan nilai puluhan dan satuan. Hal itu dilihat ketika guru memberi pertanyaan $60+4$, siswa $S$ $1 B$ tepat menjawab 64, hanya saja kesulitan yang dihadapi siswa ketika menentukan nilai puluhan dan satuan, siswa menuliskan sesuai yang siswa baca yaitu enam puluh $=60$ dan empat $=4$, yang akhirnya jika disatukan menjadi 604. Berikut kesalahan siswa S-1B dalam menjawab pertanyaan dapat dilihat pada Gambar 1 berikut.

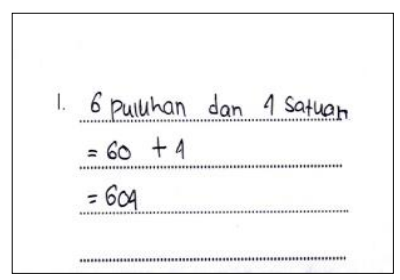

Gambar 1. Kesalahan siswa S-1B
Siswa belum memahami dengan benar aturan konsep dalam nilai tempat. Hal ini karena penempatan posisi dan cara baca suatu bilangan yang tepat sangat memperlihatkan siswa yang paham dengan siswa yang tidak memahami materi nilai tempat. Kesulitan siswa dalam memahami konsep juga diungkapkan oleh guru GK-01 saat wawancara bahwa beberapa siswa kesulitan untuk memahami materi nilai tempat.

Selanjutnya

berdasarkan wawancara dengan guru GK-01 peneliti juga menemukan bahwa siswa kesulitan memahami memahami konsep operasi menjumlah bilangan dengan satu kali teknik menyimpan dan mengurangkan bilangan dengan satu kali teknik meminjam, siswa belum menguasai sepenuhnya prosedur penjumlahan bilangan dengan cara menyimpan pengurangan bilangan dengan cara meminjam, hal ini terlihat ketika peneliti melakukan wawancara dengan siswa S-1B siswa kebingungan mengerjakan soal dikarenakan tidak dapat membedakan bilangan yang disimpan dan bilangan yang dipinjam.

Kesulitan pada materi penjumlahan dan pengurangan ditemukan peneliti dikelas II, berdasarkan observasi dan wawancara di kelas II, peneliti juga menemukan materi penjumlahan dan pengurangan sebagai materi yang sulit, saat melakukan pengamatan, beberapa siswa belum siswa memahami konsep operasi penjumlahan dengan cara menyimpan dan operasi pengurangan dengan cara meminjam. Siswa mempunyai miskonsepsi pada operasi pengurangan yang melibatkan bilangan nol. Hal ini dibuktikan dengan observasi ketika siswa mengerjakan soal misalnya $30-8=38$, siswa menganggap $0-8=8$. Berikut kesalahan siswa S-2A dalam 
menjawab pertanyaan dapat dilihat pada Gambar 2 berikut.

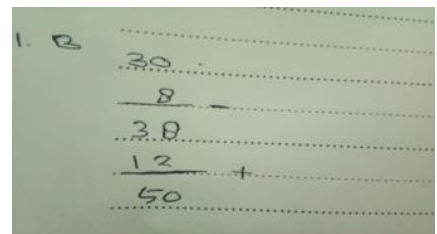

Gambar 2. Kesalahan siswa S-2A

Selain itu, siswa kesulitan mengerjakan pengurangan dengan cara meminjam, dimana siswa tidak memperhatikan dampak dari proses peminjaman bilangan tersebut. Sebaliknya, siswa kesulitan mengerjakan soal penjumlahan dengan cara menyimpan, dimana siswa tidak memperhatikan dampak dari proses penyimpanan bilangan tersebut.

Selain materi penjumlahan dan pengurangan, siswa kelas II menganggap materi perkalian dan pembagian sebagai materi yang sulit, berdasarkan wawancara dengan guru GK-2 siswa belum memahami konsep perkalian sebagai penjumlahan berulang. Siswa belum mengenal konsep perkalian dengan baik tetapi mencoba menghafalkan perkalian tersebut. Hal ini dapat menimbulkan kekeliruan jika hafalannya salah. Sebaliknya dengan pembagian, siswa belum paham konsep pembagian dengan pengurangan berulang. Selanjutnya materi yang dianggap sulit oleh siswa kelas II adalah operasi hitung campuran, siswa kesulitan dengan urutan langkah penyelesaian. Hal ini dibuktikan pada saat observasi siswa S-2C kesulitan mengerjakan soal operasi hitung campuran dikarenakan bingung dengan urutan penyelesaian.

Selanjutnya berdasarkan observasi dengan siswa kelas III, siswa masih kesulitan memahami konsep penjumlahan dengan dua kali teknik menyimpan dan pengurangan dengan dua kali teknik meminjam. Hal ini disebabkan siswa kurang menguasai konsep penjumlahan dan pengurangan di kelas I dan II, siswa kebingungan ketika mengerjakan soal dengan dua kali teknik menyimpan. Berikut kesalahan siswa S-3B dalam menjawab pertanyaan dapat dilihat pada Gambar 3 berikut.

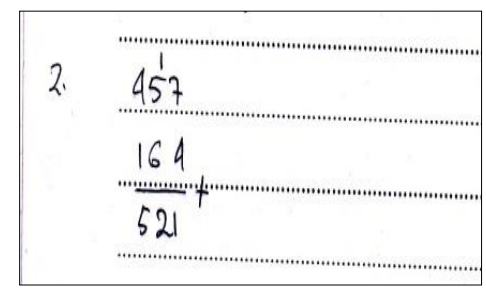

Gambar 3. Kesalahan siswa S-3B

Selanjutnya pada observasi pembelajaran di kelas III. peneliti menemukan bahwa siswa belum memahami konsep pembagian dua angka, siswa kesulitan menempatkan angka yang ada pada tempatnya sesuai dengan nilai satuannya. Seringkali siswa menukar tempatnya sehingga hasilnya salah serta kesulitan dalam memahami nilai satuan tiap angka dalam soal.

\section{b. Kesulitan dalam Keterampilan Perhitungan}

Kesulitan dalam keterampilan berhitung dapat dilihat dari kesalahan yang dilakukan siswa saat melakukan operasi hitung seperti operasi penjumlahan, pengurangan, perkalian dan pembagian. Materi kelas I yang menuntut siswa melakukan operasi hitung adalah materi penjumlahan dan pengurangan. Kesulitan siswa pada materi operasi hitung menjumlah bilangan dengan satu kali menyimpan dan mengurangkan bilangan dengan satu kali teknik meminjam. Siswa dalam menyelesaikan soal terlihat kurang teliti melakukan perhitungan. Hal ini didukung oleh wawancara dengan siswa S-1C, siswa kurang teliti dalam melakukan perhitungan.

Selanjutnya, kesulitan dalam keterampilan berhitung juga dialami oleh siswa kelas II, berdasarkan 
wawancara dengan guru GK-2 siswa kelas II kurang teliti dalam melakukan perhitungan pada materi penjumlahan, pengurangan, perkalian dan pembagian. siswa belum mampu menghitung dengan baik, kurangnya penguasaan keterampilan berhitung inilah yang membuat siswa kesulitan dalam proses pembelajaran. Hal ini juga dibuktikan dengan wawancara siswa S-2B, siswa tidak teliti melakukan perhitungan ketika mengerjakan soal.

Tidak jauh berbeda dengan kelas III kesulitan siswa dalam keterampilan berhitung dikarenakan siswa belum menguasai keterampilan berhitung saat duduk di kelas II. Hal ini dibuktikan dengan wawancara guru GK-3, Kurangnya penguasaan keterampilan berhitung di kelas II membuat siswa kesulitan mengikuti materi kelas III yang berkaitan dengan penjumlahan, pengurangan, perkalian dan pembagian. Berdasarkan wawancara dengan siswa S-3B, siswa merasa sudah mengerjakan soal dengan teliti namun ternyata jawaban mereka masih salah.

\section{c. Kesulitan Memecahkan Masalah}

Dalam pemecahan masalah biasanya melibatkan beberapa kombinasi konsep dan keterampilan dalam situasi baru atau situasi yang berbeda dari yang sebelumnya. Peneliti menemukan siswa kesulitan memecahkan masalah dalam bentuk soal cerita. Salah satu contoh soal yang menunjukan kesulitan siswa dalam memecahkan masalah adalah soal cerita pada materi penjumlahan dan penggurangan.

Berdasarkan wawancara dengan guru GK-1 siswa terkadang sulit untuk memahami maksud dari pernyataan yang ada dalam buku ataupun LKS. Guru mengungkapkan bahwa saat mengkoreksi pekerjaan siswa ditemui yang salah mengartikan maksud dari soal sehingga tidak memperoleh jawaban yang diinginkan, siswa kesulitan memahami istilah-istilah matematika yang terdapat dalam soal.

Kesulitan memecahkan masalah dalam bentuk soal cerita pada materi perkalian dan pembagian, siswa kesulitan menalar dan mengilustrasikan kata perintah dalam soal, perintah yang seharusnya dibagi menjadi dikali atau dikurangi. Pada akhirnya operasi hitung yang tersusun juga mengalami kesalahan begitu juga hasilnya. Berikut kesalahan siswa S3C dalam menjawab pertanyaan dapat dilihat pada Gambar 4 berikut

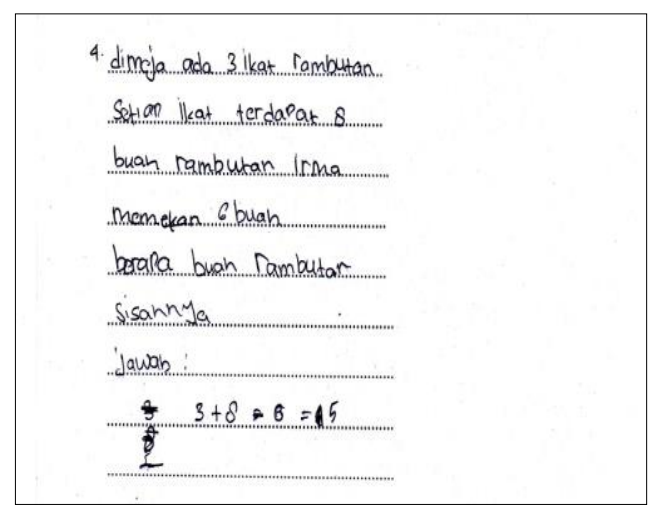

Hal ini dibuktikan dengan wawancara siswa S-3B, Siswa masih sulit memahami soal dimana siswa sering bertanya maksud dari soal tersebut kepada guru dan sering keliru menuliskan informasi pada soal sebelum menjawab soal cerita.

\section{d. Kesulitan dalam Memahami Simbol}

Berdasarkan wawancara dengan guru GK-1 siswa memiliki kekurangpahaman tentang simbol, anak-anak umumnya tidak terlalu mengalami kesulitan jika kepada mereka disajikan soal-soal seperti $5+$ $2=\cdots$, atau $7+2=\cdots$, akan tetapi merasa kesulitan jika dihadapkan pada soal-soal seperti $6+\cdots=11 ; \ldots-3=$ 6, kesulitan semacam ini, umumnya karena anak tidak memahami simbolsimbol seperti seperti $(=)$, tidak sama dengan $(\neq)$, tambah $(+)$, kurang $(-)$. 
Hal ini dibuktikan dengan wawancara siswa S-1B, siswa bisa membedakan tanda tambah (+) dan kurang (-) tetapi masih bingung mengejakan soal mengenai sifat pertukaran. Selanjutnya kesulitan memahami simbol dialami juga oleh siswa kelas II dan III pada materi perbandingkan bilangan. Siswa kesulitan membandingkan bilangan menggunakan simbol lebih besar $(>)$ dan lebih kecil $(<)$, berdasarkan wawancara dengan guru siswa selalu tertukar menggunakan simbol lebih besar $(>)$ dan lebih kecil $(<)$.

\section{e. Penggunaan Proses yang Keliru}

Berdasarkan observasi dan wawancara dengan guru GK-2, dalam proses penyelesaian soal siswa sering mengalami kekeliruan dalam menggunakan proses perhitungan. Kekeliruan dalam proses perhitungan dalam dilihat pada materi penjumlahan dan pengurangan bilangan bersusun, digit ditambahkan dari kiri ke kanan dan tidak memperdulikan nilai tempat, bilangan yang besar dikurangi bilangan yang kecil tanpa memperhatikan nilai tempat.

\section{Faktor-faktor Penyebab Kesulitan Kesulitan Belajar Matematika Kelas I, II \& III.}

Dari pendapat ahli mengenai faktorfaktor yang mempengaruhi kesulitan belajar, peneliti menyusunnya menjadi intrumen wawancara. Beradasarkan hasil wawancara kepada siswa dan guru dan observasi didalam pembelajaran matematika kesulitan belajar matematika disebabkan oleh faktor internal dan faktor eksternal. faktor-faktor yang menjadi penyebab kesulitan belajar siswa sebagai berikut.

\section{a. Faktor Penyebab Kesulitan Belajar Secara Internal}

1) Sikap Belajar Matematika Siswa Berdasarkan wawancara dengan guru dalam pembelajaran guru GK-1 mengungkapkan memang terdapat berbagai macam sikap yang ditunjukan siswa. Terdapat siswa yang kurang memperhatikan atau bahkan mengganggu teman yang lain saat belajar, tetapi ada pula siswa yang memperhatikan. Hal ini juga dibuktikan dengan siswa S-1B, siswa mengganggu temannya saat proses pembelajaran berlangsung. Berdasarkan pengamatan juga ditemui siswa yang beberapa kali ditegur guru karena siswa mengganggu teman sebangkunya. Siswa juga mengungkapkan bahwa pada saat pembelajaran siswa memperhatikan tetapi saat ditengah jam pelajaran siswa merasa bosan.

Peneliti juga menemukan sikap siswa terhadap pembelajaran matematika juga secara keseluruhan beragam, ada yang menyenangi pelajaran matematika dan ada juga yang tidak menyukai pelajaran matematika. Seperti wawancara dengan S-2A, siswa tidak menyukai matematika dikarenakan matematika merupakan pelajaran yang sulit. Sikap negatif siswa terhadap pembelajaran matematika mempengaruhi siswa dalam mengikuti proses pembelajaran.

\section{2) Minat Belajar Matematika Siswa}

Berdasarkan pengamatan peneliti minat belajar matematika siswa S-1B siswa tidak memperhatikan guru ketika pelajaran berlangsung. Selanjutnya beberapa siswa mengungkapkan bahwa siswa tidak menyukai pelajaran matematika. Selain itu, minat yang kurang juga dapat dilihat dari hasil observasi peserta didik cepat bosan dalam mengikuti pembelajaran matematika terlihat dari siswa melakukan kegiatan lain seperti mengajak ngobrol teman sebangku.

Minat belajar dari dalam individu sendiri merupakan faktor yang sangat dominan dalam pengaruhnya pada kegiatan belajar, karena jika dalam diri 
individu tidak mempunyai kemauan atau minat untuk belajar maka pelajaran yang diterimanya hasilnya akan sia-sia. Berdasarkan hasil wawancara, observasi dan dokumentasi dapat dijelaskan temuan peneliti menunjukan bahwa minat peserta didik kurang dalam pembelajaran matematika mengakibatkan sulit untuk menerima atau melakukan suatu aktivitas belajar yang berhubungan dengan mata pelajaran matematika yang berakibat dapat mengalami kesulitan dalam pembelajaran matematik.

\section{3) Motivasi Belajar Matematika} Siswa

Berdasarkan wawancara dengan guru diketahui bahwa motivasi siswa untuk belajar rendah tetapi juga terdapat siswa yang memiliki motivasi belajar tinggi. Motivasi belajar siswa dapat diketahui dari persiapan siswa dalam pembelajaran matematika. Siswa dengan motivasi yang kuat akan senang belajar matematika meskipun tidak ada PR atau ulangan keesokan harinya. Namun siswa yang mengalami kesulitan belajar matematika memiliki motivasi yang rendah, mereka tidak mengulang kembali materi yang telah disampaikan atau mempelajari terlebih dahulu materi yang akan disampaikan. Hal ini dibuktikan dengan wawancara siswa $\mathrm{S}$ 2B, siswa belajar jika ada PR atau ulangan.

Berdasarkan wawancara dengan guru GK-1 guru sudah memberikan motivasi siswa secara lisan melalui kata-kata dan contoh nyata siswa yang berhasil dalam pelajaran. Selain memberi motivasi secara lisan guru juga memberi motivasi dengan memberikan reward atau pehargaan agar siswa yang belum bisa terdorong untuk bisa dalam belajarnya. Namun, motivasi dari guru tanpa dukungan orang tua tidak akan memberikan dampak yang berarti untuk siswa.

4) Kemampuan Penginderaan dan Kesehatan Tubuh

Kesehatan adalah salah satu faktor penting untuk menajalankan aktivitas belajar matematika. Siswa yang kurang sehat akan mengalami kesulitan dalam belajarnya. Berdasarkan wawancara dengan siswa, kesehatan yang buruk hingga membuat siswa sering tidak masuk sekolah mengakibatkan siswa tertinggal materi pelajaran. Kondisi tersebut turut menjadi penyebab siswa mengalami kesulitan pelajaran matematika. Hal ini berdasarkan wawancara dengan guru, siswa yang kesehatannya buruk dan tidak masuk sekolah tertinggal pelajaran.

Gangguan penglihatan akan mengganggu siswa dalam menerima informasi khususnya dalam pembelajaran matematika. Dari hasil wawancara dengan guru GK-2 ada satu siswa yang mengalami gangguan penglihatan. Siswa yang kurang dalam penglihatan perlu mendapatkan penanganan khusus, hal ini menjadi perhatian khusus bagi guru GK-2. Mengetahui siswanya ada mengalami gangguan penglihatan yaitu mata silinder, beliau menempatkan siswa tersebut di bangku paling depan bagian tengah agar tetap dapat melihat papan tulis dengan jelas.

\section{b. Faktor Kesulitan Belajar Secara Eksternal}

1) Penggunaan Media Pembelajaran.

Siswa sekolah dasar belum berpikir secara abstrak, untuk itu penggunaan media pembelajaran menjadi faktor penting yang perlu diperhatikan dalam pembelajaran matematika agar siswa dapat memahami konsep matematika dengan baik. Pentingnya penggunaan media untuk membantu pemahaman siswa sudah disadari oleh guru. Berdasarkan wawancara dengan guru GK-2, guru 
memilih memanfaatkan lingkungan sekitar sekolah sebagai media pembelajaran yang dapat menarik perhatian siswa. Guru menyadari pentingnya penggunaan media dalam pembelajaran matematika, namun terkadang guru mengalami kendala dalam memilih media yang tepat sesuai dengan materi yang disampaikan. Hal ini sesuai dengan wawancara dengan siswa S-2C bahwa guru menggunakan media tergantung materi, tidak semua materi menggunakan media pembelajaran.

\section{2) Sarana dan Prasarana di Sekolah}

Berdasarkan observasi pada saat proses pembelajaran yang berlangsung dikelas, sarana dan prasarana telah mendukung proses pembelajaran matematika. Kondisi kelas dapat dikatakan baik, bangunan gedung adalah bangunan permanen yang aman digunakan untuk belajar. Ruangan kelas hanya dilengkapi dengan satu kipas angin yang berfungsi sehingga kurang mendukung kenyamanan belajar. Hal ini dibuktikan dengan wawancara siswa S-3C, pelajaran matematika yang di jadwalkan di siang hari, membuat konsentrasi siswa kurang di karenakan kondisi kelas yang ramai dan panas.

3) Lingkungan Keluarga

Lingkungan keluarga merupakan faktor yang penting dalam menunjang proses siswa dalam belajar. Perhatian orang tua menunjang pembelajaran siswa dirumah. Beberapa siswa mengungkapkan bahwa saat belajar di rumah jarang ditemani orang tua, tetapi kadang ditemani saudara. Siswa menungkapkan bahwa orang tua jarang menanyakan kegiatan siswa di sekolah. Berdasarkan wawancara guru ada beberapa siswa yang tidak mengerjakan pekerjaan rumah, pekerjaan rumah yang diberikan guru bertujuan agar siswa belajar lagi dirumah dan bertanya kepada orang tua jika mengalami kesulitan, namun guru menemui siswa yang berkesulitan belajar matematika tidak mengerjakan PR yang telah diberikan, hal tersebut dapat menjadi indikasi kurangnya perhatian orang tua, hal ini disebabkan kurangnya perhatian orangtua.

Berdasarkan wawancara dengan siswa S-1B siswa sering tidak mengerjakan PR karena lupa mengerjakan. Hal ini juga diungkapkan oleh guru GK-1, siswa S1B kurang perhatian orang tua, siswa S-1B merupakan korban broken home sehingga jarang mendapat perhatian orang tua. Siswa juga mengungkapkan bahwa saat belajar dirumah siswa dengan keadaan ramai, siswa belajar diruang tamu dan di depan TV bersama keluarga yang lain.

\section{Hambatan Dalam Mengenali Penyebab Kesulitan Belajar Matematika Siswa Kelas I, II \& III \\ a. Lingkungan Sekolah}

Dari hasil wawancara yang dilakukan peneliti selama kegiatan pembelajaran matematika di dalam kelas ditemui beberapa hambatan yang dialami oleh guru. Hal ini memberi hambatan kepada guru saat proses belajar mengajar berlangsung. Siswa sering kali tidak fokus dan kurang berkosentrasi saat guru menyampaikan materi. Perhatian siswa tidak sepenuhnya ke guru saat pembelajaran matematika berlangsung. Hal ini sesuai dengan wawancara siswa GK-1, siswa sering tidak memperhatikan guru saat pembelajaran berlangsung. Hal ini dikarenakan saat pembelajaran berlangsung, siswa kelas lain berlalu lalang di depan kelas, keramaian tersebut membuat konsentrasi dan perhatian siswa menjadi tidak fokus.

\section{b. Motivasi dan Sikap Siswa}

Berdasarkan hasil observasi dan wawancara selama melakukan penelitian, peneliti melihat bahwa guru sudah 
memberikan motivasi kepada siswa. Ditunjukan saat GK-1 mengajak siswa untuk bersemangat untuk mengikuti pelajaran matematika sebelum proses pembelajaran dimulai. Selain itu guru memberi motivasi melalui pemberian reward berupa pujian kepada siswa. Motivasi guru sudah dilakukan selama pembelajaran matematika berlangsung. Terkait dengan perhatian siswa saat belajar di kelas tidak fokus menjadi salah satu hambatan bagi guru. Berdasarkan hasil observasi, peneliti melihat siswa masih kurang dalam memperhatikan guru ketika menjelaskan materi. Masih ada beberapa siswa yang mengobrol, melakukan kegiatan lain seperti bermain alat tulis, mencoret-coret buku dan mengajak ngobrol temannya. Kegiatan yang dilakukan siswa-siswa tersebut mengurangi kosentrasi dan perhatian siswa pada proses pembelajaran.

\section{KESIMPULAN}

Berdasarkan hasil penelitian dan pembahasan Studi Kasus Kesulitan Belajar Matematika Siswa Kelas I, II \& III di SD Negeri 009 Balikpapan Selatan, diperoleh simpulan sebagai berikut.

a. Terdapat siswa mengalami kesulitan dalam pembelajaran matematika pada pokok bahasan bilangan cacah yaitu kesulitan dalam memahami konsep, kesulitan dalam keterampilan berhitung, kesulitan dalam pemecahan masalah matematika, kesulitan memahami simbol dan penggunaan proses yang keliru.

b. Faktor-faktor yang menyebabkan siswa berkesulitan belajar siswa pada pokok bahasan bilangan cacah berasal dari faktor internal dan eksternal. Faktor internal yang berasal dari siswa meliputi sikap siswa dalam belajar matematika, motivasi siswa yang masih rendah, minat belajar siswa yang masih rendah, kesehatan tubuh yang tidak optimal dan kemampuan penginderaan siswa yang kurang. Sedangkan faktor eksternal yang berasal dari luar siswa antara lain penggunaan media pembelajaran yang belum maksimal, sarana dan prasarana serta lingkungan keluarga.

c. Hambatan dalam mengenali penyebab kesulitan belajar siswa pada pelajaran matematika pokok bahasan bilangan cacah adalah lingkungan sekolah yaitu lingkungan belajar siswa yang kurang kondusif, motivasi dan sikap yaitu kurangnya perhatian siswa dalam proses pembelajaran matematika.

\section{DAFTAR PUSTAKA}

Abdurrahman, M. (2010). Pendidikan Anaka Berkesulitan Belajar. Jakarta: Rineka Cipta.

Jamaris, M. (2014). Kesulitan Belajar Perspektif, Asesmen, dan Penanggulangannya. Bogor: Ghalia Indonesia.

Rusgiarti. (2014, Juni). Studi Kasus Tentang Kesulitan Belajar Mata Pelajaran Biologi di Kelas VII Sekolah Menengah Pertama Negeri 15 Pontianak. Jurnal Edukasi, Volume I Nomor 1, 102110.

Sugiyono. (2014). Metode Penelitian Pendidikan Pendekatan Kuantitatif, Kualitatif, dan $R \& D$. Bandung: ALFABETA.

Untari, E. (2013). Diagnosis Kesulitan Belajar Pokok Bahasan Pecahan Pada Siswa Kelas V Sekola Dasar. Jurnal Ilmiah STKIP PGRI Ngawi, Volume XIII Nomor 1, 1-8.

Yeni, E. M. (2015, September). Kesulitan Belajar Matematika di Sekolah Dasar. JUPENDAS, Volume II Nomor 2, 1-10. 